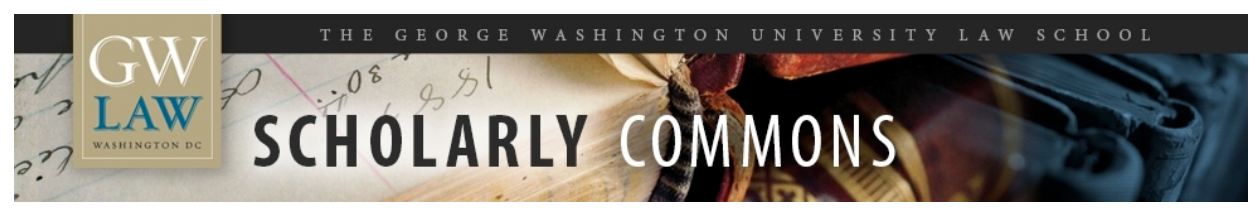

\title{
The Middle Way: What Contemporary Liberal Legal Theorists Can Learn from Aristotle
}

\author{
Miriam Galston \\ George Washington University Law School, mgalston@law.gwu.edu
}

Follow this and additional works at: https://scholarship.law.gwu.edu/faculty_publications

Part of the Law Commons

\section{Recommended Citation}

Miriam Galston, The Middle Way: What Contemporary Liberal Legal Theorists Can Learn from Aristotle in ARISTIDE TESSITORE, ARISTOTLE AND MODERN POLITICS (Christina Catanzarite, ed., University of Notre Dame Press, 2002).

This Article is brought to you for free and open access by the Faculty Scholarship at Scholarly Commons. It has been accepted for inclusion in GW Law Faculty Publications \& Other Works by an authorized administrator of Scholarly Commons. For more information, please contact spagel@law.gwu.edu. 


\title{
THE MIDDLE WAY: \\ WHAT CONTEMPORARY LIBERAL LEGAL THEORISTS \\ CAN LEARN FROM ARISTOTLE
}

\author{
Miriam Galston
}

American legal theorists have long been preoccupied with questions about method and truth in legal and moral reasoning. Their inquiries have focused on whether and how citizens, lawmakers, judges, and other public officials can attain truth, correctness, or certainty in their legal and moral pronouncements. ${ }^{1}$

Until the last decades of the nineteenth century, American legal theory was dominated by formalist views, which saw legal reasoning in the ideal case as a closed, deductive system based upon a finite number of foundational principles and rules. By the beginning of the twentieth century, formalism as an ideal was under attack by adherents of legal realism and sociological jurisprudence. ${ }^{2}$ Members of the latter two schools of thought argued that the legal system was in fact and of necessity uncertain and imprecise, assessed by such measures as the lack of predictability of judicial decisions and the absence of a unique, correct solution to particular legal questions. The source of legal uncertainty was explained by members of these schools of thought in terms of one or more of the following circumstances. For some, the law's foundational principles, statutory and common law rules, and specific judicial decisions do not form a coherent whole. Therefore, reliance on them can yield inconsistent, even contradictory results. Others argued that the human and commercial situations to which law applies are themselves constantly changing. As a result, legal structures will have to be altered (deliberately or otherwise) on a more or less continuous basis to fit the reality they purport to govern. Alternatively, the uncertainty of 
legal determinations was seen as attributable to the fact that applying general rules to specific fact patterns is rarely mechanical. This makes moral and legal determinations a question of judgment and enables, if not encourages, judges to look to considerations outside what is explicit or clearly implicit in precedent to adjudicate concrete cases. Finally, some of the critics of the formalist ideal emphasized that people who engage in moral and legal reasoning - whether as theorists, lawmakers, judges, or citizens - will necessarily be influenced by personal, class, or cultural biases that affect the manner in which they interpret or apply existing legal materials.

For some of the challengers to formalist legal theory, the fluid nature of law and the indeterminate nature of legal reasoning were seen as defects, i.e., as departures from an ideal of perfectly syllogistic and certain reasoning that, consciously or unconsciously, they shared with the formalists. ${ }^{3}$ For others, the uncertainty of the law is, at least in part, a consequence of the law's need to respond to complex and evolving "social, industrial and political" realities and, hence, it is a primary cause of the law's "immense social value."

The desire of legal theorists to determine whether and how reasoning about human affairs can attain correct outcomes has continued to the present day. In the last several decades, these epistemological concerns have been expressed differently than in the early part of the century. At one end of the contemporary legal theory spectrum, there is renewed interest in formalist-type theories, such as neo-Aristotelian natural law theory. ${ }^{5}$ However, the earlier natural law ideal of searching for unchanging truths about human nature and human affairs that are in principle universally binding and should be used to evaluate the correctness of particular moral and legal determinations has given way to alternative notions of natural law, some of which are free of unitary interpretations of human nature and 
morality. ${ }^{6}$

At the other end of the spectrum are schools of thought-- such as critical legal studies ("CLS"), critical race theory, ${ }^{8}$ some feminist approaches, ${ }^{9}$ law as narrative, ${ }^{10}$ different voice scholarship, ${ }^{11}$ and poststructuralism $^{12}$-- that celebrate what Suzanna Sherry calls "nonrational epistemologies, ${ }^{\text {"13 }}$ such as relativism, ${ }^{14}$ subjectivism, "radical particularism, ${ }^{115}$ radical social constructivism, ${ }^{16}$ decisionism, ${ }^{17}$ and nihilism. ${ }^{18}$ The doctrines at this end of the legal theory spectrum explicitly challenge the possibility of rational legal and moral discourse at the same time that they repudiate the substantive bodies of thought connected with traditions of such discourse.

Between the two extremes are numerous contemporary legal theorists who have attempted to mark out territory that is neither objectivist or formalist, on the one hand, nor subjectivist or relativist, on the other. These authors, whom I call theorists of the middle way, reject the idea that knowledge must be absolute and unchanging to be worthy of the name. Aristotle provides theoretical grounds for their intuition: at the beginning of the Nicomachean Ethics he observes that

precision cannot be expected in the treatment of all subjects alike....[W]hen the subject and basis of a discussion consists of matters that hold good only as a general rule, but not always, the conclusions reached must be of the same order....For a well-schooled man is one who searches for that degree of precision in each kind of study which the nature of the subject at hand admits.... ${ }^{19}$

For Aristotle, in other words, rejection of the formalist ideal of reasoning demonstratively to a determinate conclusion is not a practical concession to the limitations of human cognition. ${ }^{20}$ Nor does it mean that the results of inquiry about matters not amenable to precision must be anything less than the truth. ${ }^{21}$ Aristotle's epistemological observations thus call into question the dichotomy between universal knowledge and everything else on the ground that it reflects a misunderstanding of the relationship 
between knowledge and its object in connection with human affairs. Rather than being apologetic about the limits of their understanding, legal theorists should seek to understand why much of human conduct is not and cannot be captured by absolute, universal rules.

Although precision may be neither possible nor appropriate when reasoning about certain aspects of human affairs, there are nonetheless standards to guide or issue from such inquiries. Middle way theorists, by definition, assume such standards because their theories agree that such reasoning is not simply arbitrary or ad hoc. Two distinct approaches of contemporary liberal legal theory of the middle way that can learn from Aristotle will be discussed in this essay. ${ }^{22}$ The first is characterized by a reluctance to have recourse to substantive moral and political principles that exist independently of a particular legal order. The second approach, in contrast, is characterized by a willingness to recognize and incorporate such principles into reasoning about human affairs Because of the reluctance of theorists of the first type for legal reasoning to have recourse to substantive standards into legal reasoning, other than those derived from a constitution, statutes, and judicial precedents, this approach relies to a much greater degree than the second on the process of communal deliberation and on various structural, procedural, and related devices constraining deliberation to reach decisions about human values and conduct.

\section{The Process-Oriented Middle Way Approach}

Liberal legal theorists of the middle way who are reluctant to impose or even propose external substantive standards to guide the legal reasoner have developed approaches to moral and legal reasoning that depend upon theories of practical reason as wholly or mostly independent of universal

principles and rules, yet not arbitrary or ad hoc. ${ }^{23}$ Their wariness about developing external substantive 
standards as part of a theory of practical reasoning stems in large part from one or more of four beliefs: that we do not in fact know definitively which goals and values are superior; that we cannot attain such knowledge even if we try; that our ability to evaluate goals and preferences correctly is in any event politically irrelevant because the goal of public life should be to ensure the conditions of the private pursuit of life plans rather than to encourage people to pursue one or more publicly designated life plans-whether that restriction is for the sake of reducing political conflict or to make possible the autonomy of individuals; and that the content of human happiness or the common good is not unitary or uniform.

Arguably all of these reasons are epistemological at bottom. Although it is true that at present the contemporary liberal legal commitment to diversity and autonomy seems to be based upon a belief in the intrinsic value of these objectives, it is possible that this commitment originally came into being as a result of, and is currently reinforced by, the more basic belief that human reason is incapable of proving definitively the superiority of one or more conceptions of the human good.

Because of the preceding considerations, many contemporary middle way theorists with a process orientation have in common the belief that government actors and institutions should not favor the goals and values of one sub-group of the larger community over another, regardless of whether they originate in religious, moral, or cultural concerns of the sub-group. ${ }^{24}$ Relatedly, the task of legal theory is to describe the structural, procedural, and related conditions that must exist so that individuals or communities can themselves understand which values they should hold, what outcomes they should pursue, and how to pursue them. It is characteristic of these theories to describe some form of group discourse as the best vehicle for making practical decisions with respect to values or actions. ${ }^{25}$ The 
conclusions reached and consented to in the group discussions envisioned by these theories are seen as both valid and validated because of the qualities of the participants in the reasoning process, in particular, because of their equality as participants, their being informed or becoming informed (through the group discourse) before reaching conclusions, their seriousness about the process, the respect they accord one another, and their willingness to learn and grow from the give and take among the participants. ${ }^{26}$ For such theorists, substantive standards are the product, not the precondition, of communal deliberation. ${ }^{27}$

$\underline{\text { An Aristotelian Appraisal of the Process-Oriented Middle Way Approach }}$

The attempt to avoid the extremes of objectivism and subjectivism without relying upon extralegal substantive standards can be illuminated and, in some respects, refined by turning to Aristotle's observations about moral theory and phronesis or practical reason. Four features of the thought of process-oriented middle way theorists are especially worth examining from an Aristotelian perspective: (1) the preference for communal debate over individual investigation, (2) the importance for selfgovernance of consent by an individual to rules he has participated in creating, (3) the aspiration to selfgovernment and transformative political participation, and (4) the insistence on ideal speech conditions as a precondition for legitimate communal debate.

Communal reasoning. The preference on the part of contemporary liberal legal theorists for reasoning about human affairs in a communal setting is grounded, among other reasons, in the belief that when people put their opinions forward in a public forum in an attempt to persuade others, the communal scrutiny that results is likely to weed out obvious errors and increase the range and depth of information bearing upon the topic at hand. The result of deliberative encounters, according to this 
view, should be sounder, more informed beliefs or decisions than would be possible if individuals reason in isolation.

There is a substantial amount of support for the usefulness of communal inquiry in Aristotle's writings. It is a hallmark of his own investigations to begin with a review of what others have said on the topic under discussion and to weigh what appear to be the strengths and weaknesses of these points of view. ${ }^{28}$ In addition to canvassing the opinions of experts, living and dead, Aristotle can be said to consider the opinions of the reader and others living in Athens, since he frequently tests the opinions of other authorities against "what people think" or what "seems to be the case." Aristotle thus makes use of the opinions of individuals and groups, past and present, along with other analytical tools to put the most likely alternatives on the table for evaluation.

The theoretical justification for Aristotle's method is contained in his Topics, where he discusses the nature and mechanics of dialectical reasoning. Dialectical reasoning, according to Aristotle, reasons in a strict syllogistic fashion from generally accepted opinions. ${ }^{29}$ Because the logical structure of dialectical reasoning is syllogistic, if two dialectical arguments reach contradictory conclusions, the source of the contradiction is in the premises, not the form, of the argument. As a consequence, dialectical reasoning can help people identify two generally accepted opinions only one of which (at most) can be true. It thus focuses attention on the likely locus of error, enabling the reasoner to examine the suspect opinions more closely. ${ }^{30}$ Generally accepted opinions, for Aristotle, are those that seem to be right "to all or to the majority or to the wise-that is, to all the wise or to the majority or to the most famous and distinguished of them., ${ }^{, 31}$

Aristotle's explanation of the reason why playing the opinions of some people off against those 
of others can facilitate the search for truth thus supports some aspects of the beliefs of contemporary legal theorists about the importance of communal inquiry. It departs from them in important ways, however. First, Aristotle appears to equate the effectiveness of face-to-face encounters among living people with imagined encounters among dead people or people living but not present at the discussion. ${ }^{32}$ Readers of Aristotle's books, for example, are expected to learn about the topic discussed by having a conversation with its author. ${ }^{33}$ This raises the question of what the contemporary legal thinkers under discussion believe face-to-face discussions contribute as a result of the physical proximity of the participants.

Second, Aristotle and these legal theorists assign different weights to the opinions of individuals. For Aristotle, only generally accepted opinions can serve as the basis of dialectical (as opposed to rhetorical or sophistical) argument. Since opinions are said to be "generally accepted" either if all or most people hold them or if they are held by one or more wise people, ${ }^{34}$ the implication is that Aristotle equates the force of the opinion of one wise man with the opinion held by all or most people. As a theoretical matter, then, generally accepted opinions carry weight for Aristotle because they are a promising source for true opinions rather than because they command widespread support. They serve as the basis of dialectical inquiry because they are presumptively, although not necessarily, correct. ${ }^{35}$ In other words, it seems that the relatively high place Aristotle accords to the opinions of all or most people is derives from his insight that the breath of agreement can serve as a proxy for wisdom.

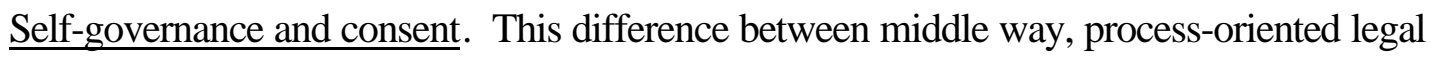
theorists and Aristotle is also related to their differing views about the importance of consent. These legal theorists rely on agreement by participants to the results of group decisionmaking to legitimate law 
for several reasons. For some, the dominant purpose of consent is to promote the values of autonomy and self-governance. Although Aristotle did not talk about "autonomy" per se, a discussion of the importance of being able to govern oneself (and be governed by others) finds pride of place in his philosophy. In the best case, he argues, the good man has the knowledge and virtue necessary to author the rules that guide his life, and not just to accept them on the authority of others. ${ }^{36}$ This is possible if, and only if, a person possesses practical wisdom or prudence. ${ }^{37}$ In contrast, the virtue of a citizen who lacks the capacity for ruling is "true opinion.".38 Aristotle thus differs from contemporary legal theorists in identifying self-governance with the active exercise of reason rather than the initiation of, participation in, or assent to rules by which a person is governed. In this regard, as was the case in connection with the importance for Aristotle of communal inquiry, agreement by those affected is only a rough approximation of the core value--reason--upon which correct decisions and self-governance rest. $^{39}$

For other legal theorists, confidence in consent as the hallmark of successful deliberative outcomes derives primarily from their uneasiness, discussed above, prompted by the distance they see between the method of practical reason and that of scientific or syllogistic reasoning. Even theorists who maintain that the lack of determinacy or predictability on the part of practical reasoning does not imply that the insights arrived at by such reasoning are arbitrary, feel greater comfort when the deliberation is open and participatory. On the face of it, their justification would be that if agreement can be reached by people with different views and objectives, the result must be more comprehensive, hence more likely to be correct, than a result reached by a single individual or small group. Thus, communal reasoning culminating in consent is sought in the name of both autonomy and correct 
outcomes.

Finally, for some process-oriented legal theorists, the possibility of consent makes deliberative encounters attractive as a solution for the peculiar and destabilizing problems of a pluralistic and liberal legal order, namely, the existence of diverse, sometimes irreconcilable values and visions of the best way to live. Given the reluctance of these theorists to impose on a population of adult individuals a unitary idea of the best course of action in particular situations much less a single account of human happiness or the common good, they place their faith in voluntary processes designed to foster a spirit of respect, cooperation, and compromise among those who participate. The attitudes thus inspired, it is hoped, will enable people to agree to solutions that they would not otherwise agree to, given their different beliefs and goals they initially hold.

From an Aristotelian perspective, it is curious to employ the practice of rational discourse to create what Aristotle would view as moral virtues, ${ }^{40}$ rather than to develop moral attitudes and behaviors to facilitate the cultivation of reason. First, Aristotle would undoubtedly favor instilling moral virtues directly, i.e., through habituation, on the ground that the process of becoming moral is more likely to be successful if begun when a child is young. ${ }^{41}$ Thus, for him habituation of children through rote imitation of the moral qualities upon which social cooperation depends would be preferable to persuading adults of the importance of such qualities, since adults may already have entrenched habits tending in a different direction. Second, as I have argued elsewhere, for Aristotle, a person needs certain moral qualities to be capable of exercising her rational faculties or being reasonable in the first place $^{42}$

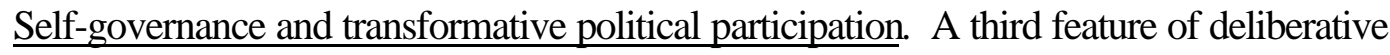


encounters according to contemporary the contemporary legal theorists under consideration is the potential transformative effect they can have on the individuals who participate. This effect is sometimes explained in terms of enabling people to develop some aspect of their mental capacities, to become moral agents, or to become fully responsible, autonomous human beings. ${ }^{43}$ Understanding deliberative encounters as transformative in this way can be seen as based, explicitly or implicitly, upon the Aristotelian dictum that man is by nature political. ${ }^{44}$ Process-oriented middle way legal theorists have a tendency to reject Aristotle's dictum if it is construed to mean that a life of engagement in politics is essential to human happiness. Rather, they argue that such a life is one, but not the unique avenue to the realization of human potential. ${ }^{45}$ Alternatively, such theorists assume that human beings' political nature should be understood as synonymous with their social nature and, thus, as consistent with many fundamentally private ways of life or membership in groups in general. ${ }^{46}$

Aristotle would almost certainly reject treating engagement in political life as interchangeable with engagement in social life or membership in groups. For Aristotle the boundary between the political community and any other type of community is well-defined and meaningful. In Book I of the

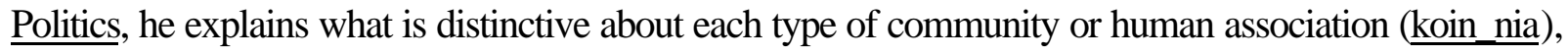
whether political or sub-political, in terms of the end that each pursues. The end of the association of man and woman is reproduction; that of master and servant, survival; that of the household, the necessities of daily life; and that of the village, daily needs that are not necessities. ${ }^{47}$ The end of the city or political community, in contrast, is the good life, or living well. ${ }^{48}$ To accomplish these differing objectives requires different faculties and skills. As a consequence, Aristotle warns the reader against imagining that fitness to govern any one type of association can be generalized to fitness to govern any 
other. $^{49}$

Based upon Aristotle's analysis, it would also be mistaken simply to assume that the human fulfilment derived from involvement in interpersonal relationships characteristic of one type of community or association is the equivalent of the human fulfilment derived from involvement in relationships characteristic of any of the others. The only way, then, to determine whether Aristotle's dictum can be translated into a statement about human sociality would be, first, to determine what he meant by a political community and which aspects of participation in such a community he believed actualized human nature and, second, to make a parallel investigation of social association and interpersonal relations of the type intended by contemporary legal theorists to determine if the latter can perform the same function as the former. ${ }^{50}$

While such a task goes beyond the scope of this essay, I believe it is fair to say that, at the very least, Aristotle would deny the equation of human nature as political and human nature as social unless the end of social association is the good life or living well. The measure to be used in an inquiry of this kind would thus be whether the end of social association is a partial good--as is the case with couples, master-servant relationships, households, and villages--or a complete good. Students of Aristotle have long wrestled with his concept of "living well.", On a high level of generality, Aristotle indicates that living well is characterized by self-sufficiency, and he suggests that it consists in acquiring and exercising the moral and deliberative virtues. ${ }^{52}$ On a more concrete level, however, Aristotle is much clearer about what happiness is not than about what it is. What is uncontested is that Aristotle rejects the popular beliefs that pleasures of the senses and/or material acquisition make up the core of happiness.

The failure to distinguish sharply between people's social and political natures thus has 
consequences for contemporary liberal legal theory. Among other things, it makes possible the view expressed by some writers that intermediate associations are significant forums for the development and exercise of civic virtue. Cass Sunstein, for example, has argued that labor unions, religious associations, women's groups, civil rights organizations, and charitable organizations may serve an important function in fostering civic virtue among their members. ${ }^{53}$ Frank Michelman expresses a belief in the desirability of active involvement in associations and other activities "outside the major, formal channels of electoral and legislative politics. ${ }^{154}$

The view that participation in pre- or sub-political associations will create or maintain civic virtue has obvious appeal. Given our enormous and diverse country, it may well be that intermediate associations bear a closer resemblance to certain aspects of the classical city than our nation as a whole ever can. In particular, such associations permit the homogeneity and personal knowledge among members that the classical republicans extolled among citizens. ${ }^{55}$ Such associations, however, appear to differ from the classical concept of the city in a decisive respect, namely, by aiming at the good of their members rather than the common good. In that event, the "civic virtue" encouraged by such associations would actually reinforce private preferences without attempting to scrutinize those preferences prior to placing them on the public agenda. ${ }^{56}$ Cass Sunstein anticipates this objection: he asserts that intermediate organizations will scrutinize existing practices critically and encourage the exercise of civic virtue, understood as the pursuit of goals other than self-interest, narrowly conceived. ${ }^{57}$ However, he gives no explanation of why this will be the case, and his conclusion seems to be contradicted by the way such organizations in fact operate.

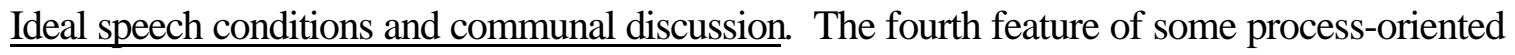


middle way legal theories is the practice of laying down specific preconditions for communal deliberations to assure the legitimacy of the deliberations and their outcomes. ${ }^{58}$ These preconditions, which are patterned after the conditions of Jürgen Habermas' ideal speech situation, ${ }^{59}$ require that all who are affected by decisionmaking be permitted to participate and that the input of all participants receive equal consideration. To achieve the latter objective, the rules require each participant to have an equal opportunity to speak, question, and express his or her point of view freely. Any form of compulsion, whether direct or indirect, is prohibited. ${ }^{60}$ Deliberative discourse is seen as successful when, despite initial disagreements, consensus is reached on a rational basis either about matters of policy or its implementation. The hallmark of the ideal speech situation is thus that it aims at understanding through rational and voluntary discourse, rather than at consensus based upon compromise, barter, or manipulation. ${ }^{61}$

From an Aristotelian perspective, once again contemporary liberal legal theorists are attempting to do indirectly what they might be more successful doing directly. Although the grounds of consensus when the ideal speech situation is achieved are rational persuasion, the rational element is expected to enter into and ultimately permeate the discourse because of the equality, honesty, and openness of the participants. This assumes that all participants (and thus, in principle, that all people) will recognize the truth of a particular point of view after an exhaustive screening process.

This assumption, however, seems to require other, arguably untenable assumptions. First, it assumes that by positing certain structural constraints on the conversation (equality, honesty, openness), the participants will exhibit certain moral qualities. In particular, it assumes that they will forgo, or cease to experience, the desire to pursue their own self-interest at the expense of the interest of others and the 
larger community, when these interests collide. Aristotle would find this expectation questionable on the basis of his belief that moral virtue must be internalized to be reliable. ${ }^{62}$ Yet he would be the first to concede that without the ability to control one's passions, deliberation is impossible. ${ }^{63}$ As was the case with the second feature of this approach discussed above, Aristotle would undoubtedly advocate instilling moderation, honesty, and a spirit of cooperation in people starting in childhood to ensure that the adult participants in a deliberative conversation will be willing to judge the opinions put forward without exclusive regard to their personal circumstances.

Second, the belief that a rational consensus can be reached in this manner seems to assume as well that all reasoning about human affairs, including moral and political reasoning, can ultimately be justified logically or empirically; without this assumption, it is difficult to understand how a deliberative discourse can issue in rational persuasion of all parties. But the notion that all of the results of deliberation can be justified logically or empirically should be objectionable to theorists who emphasize practical reason (as contrasted with deductive argument) as the path to a certain kind of practical knowledge. For Aristotle, in contrast, some, including some of the most important, determinations reached in such situations can be known only through prudence or practical wisdom, a rational process that often defies logical or empirical justification. The possessor of practical wisdom may well be guided to a large degree by precepts of a kind that can be tested and refuted. In many instances, however, the decisive variables are so numerous, complex, and interdependent that the process of reasoning cannot be broken down into a succession of linear arguments. If this is correct, the ideal speech situation would be doomed in principle unless, first, all participants possess or can come to possess practical wisdom through discussion and, second, the practical wisdom of all of them will operate identically. 
This is extremely unlikely, if for no other reason than the circumstance that practical wisdom appears to derive in large part from experience (and from the way in which individuals perceive and learn from their experiences). ${ }^{64}$ Thus, the ideal speech situation, which is premised upon equal respect for the individual participants and their differences, would be unable to reach its goal unless, when the layers are peeled back, each participant's mind is revealed to work in an identical fashion. Yet this possibility would also seem to be objectionable to theorists for whom respect for people's distinctiveness is paramount.

Aristotle would deal with this dilemma by challenging the belief that practical wisdom is a capacity that all possess (or can learn) to an equal degree. It is interesting that he embarks upon his definition of practical wisdom by studying the people to whom we attribute practical wisdom ${ }^{65}$ rather than more abstractly, as he does in the case of some other mental faculties. His approach may suggest that practical wisdom is not a generic capacity and that its workings are inseparable from the person who exercises or possesses it. Aristotle also distinguishes practical wisdom from other mental faculties that resemble it, such as shrewd guessing, calculation in the service of partial or evil ends, having correct opinions, and good sense. ${ }^{66}$ Practical wisdom thus resembles a talent that is developed through experiences of a certain kind, but it also depends in part on a natural or intrinsic core capacity of the individual. If this is the case, communal inquiries may not be able to replicate the mental process of a single person with a natural capacity and suitable experiences to actualize it.

The Middle Way Approach Open to Independent Substantive Standards

Numerous other legal thinkers who believe that reasoning about moral or legal issues can achieve correct or non-arbitrary results in the absence of logical or empirical proof adopt an approach that combines substantive and procedural elements. ${ }^{67}$ These thinkers tend to identify the rational faculty 
involved in this type of reasoning as "practical reason," "practical wisdom," "prudence," or “judgment.” In reaching decisions, judgments, or conclusions, the person exercising practical reason relies on some combination of tradition, history, formal instruction, observation, experience and reflection. ${ }^{68}$ So understood, the person engaged in practical reasoning resembles a doctor who relies upon the totality of her book and life learning to arrive at decisions in individual cases. The person engaged in moral or legal reasoning, however, faces a subject matter of far greater complexity and much less regularity than the subject of the medical arts.

Contemporary legal thinkers of the middle way who believe in the possibility of moral philosophy or moral truth ${ }^{69}$ disagree about the extent of its relevance for legal reasoning, especially the reasoning of judges or public officials. The most preeminent legal theorist who argues for independent substantive standards guiding (as well as issuing from) legal reasoning is Ronald Dworkin. His writings elaborate a theory that explains how it is possible for judges and others ${ }^{70}$ to arrive at "right answers" in hard cases, i.e., in the absence of legal principles, rules of law, or legal precedents that dictate specific conclusions. ${ }^{71}$ For Dworkin, in such cases judges first have, and should have, recourse to established legal materials (such as rules, principles, statutes, regulations, and previous judicial decisions) and the principles implicit in those materials. To prevent judges from relying on intuition or "making decisions that seem right in isolation" when they turn to principles implicit in established legal materials, ${ }^{72}$ Dworkin requires them to determine which principles are consistent with each other and with the body of settled legal materials thought to be right. ${ }^{73}$ Because of inconsistencies in established legal materials, to establish a comprehensive theory of this kind, a judge may have to prefer some of the legal materials or principles over others. ${ }^{74}$ 
Dworkin argues that, whenever the result of this process fails to account satisfactorily for established legal materials, including the principles implicit in them, or it produces more than one comprehensive theory, the comprehensive theory that best fits existing legal materials will be the one that "is superior as a matter of political or moral theory.", "It is at this stage, then, that Dworkin advocates having recourse to sources external to the law. A judge is nonetheless obliged to render decisions that defer to existing law as much as possible, consistent with the obligation to maintain the law's integrity. Moral and political philosophy are thus not free to determine the direction or content of the law except insofar as is required to enhance its integrity. ${ }^{76}$

In two recent articles, Ken Kress argues that Dworkin's methodology produces suboptimal results because it presumes that the legal theory adopted by judges who rely on external sources must aim at a high degree of fit with established legal materials. This requirement, according to Kress, is never adequately defended, ${ }^{77}$ and it prevents judges from reaching as morally correct a theory as would be possible if a less rigorous fit were required. ${ }^{78}$ Kress concedes that the jurisprudence elaborated by Dworkinian judges will improve from the standpoint of morality over time, but he argues that such a result is inadequate for a "legal system that aspires to do justice."79 At the same time, Kress acknowledges that judges have differing capacities for what he calls "critical moral truth" and that, as a consequence, the real question is not which legal theory is absolutely best in the abstract, but which theory we would want judges to adopt given their views about critical moral matters as compared with their views about the dominant ideology embedded in the settled law. ${ }^{80}$ He concludes that in the best case, i.e., when judges are well equipped to think critically about moral matters, some version of natural law theory will produce better decisions than a theory heavily tied to established legal precedents. But 
he leaves open whether such judges exist now or will likely exist in the future.

Anthony Kronman also recognizes the possibility of standards of moral truth or justice independent of a legal system, but he is wary of judges substituting moral truth or a philosophic theory of justice for existing law. Kronman argues that judges do need to engage in moral reflection to fill gaps in existing law for several reasons. ${ }^{81}$ Yet he also urges that this aspect of the judicial function be limited to infrequent occasions and that judges resist the temptation to treat law as a "subfield of morality" or a text for philosophic exegesis. ${ }^{82}$ Instead, Kronman endorses Alexander Bickel's doctrine of prudence or "good practical wisdom" as a judicial virtue. According to Bickel, judges must resist moral imperatives, cultivate the ability to "live with the disharmony between aspiration and historical circumstance," and look for "opportunities that permit the marginal and evolutionary reconciliation of our principles and practices." 83

Kronman $^{84}$ identifies the occasions on which judges should have recourse to moral principles with the educational role of courts, that is, their responsibility to "instruct and elevate, to bring out the best in us and show us where our own convictions lead." ${ }^{, 85}$ But the courts also have a responsibility to respect the democratic principle of the consent of the people and to promote peace through compromise. In his view, therefore, to be effective in their role as educators, the courts must assess and accommodate the environment in which they render decisions rather than operate as philosopherkings. 86

Christopher Eisgruber also believes that there are independent standards of justice and morality that the Constitution of the United States does not embody. Unlike Kronman or Dworkin, however, he believes that judges should completely refrain from importing these values into judicial decisions. He 
reasons that Constitutional norms already reflect a commitment to justice, albeit imperfect, and this level of justice is superior to philosophic norms from a political point of view, i.e., because it reflects standards that can realistically gain the consent of the people over the long-term. For Eisgruber, then, Constitutional norms are desirable from a moral point of view because they are substantively good (as well as attainable). Prudent judges should therefore pursue a fuller realization of Constitutional norms rather than try to modify them in light of external standards. ${ }^{87}$

\section{An Aristotelian Appraisal of the Middle Way Theories Open to External Standards}

Despite their differences, these theories echo important aspects of Aristotle's understanding of the way values and actions should be understood and ranked. All of the legal theorists discussed in the preceding section envision a form of practical reasoning that can be employed in deciding difficult legal questions in the absence of clear answers based upon established legal materials. Their descriptions of the reasoning process share with Aristotle's an expectation that practical reason arrives at judgments by taking into account a combination of principles, rules of varying degrees of generality, and particular features of individual situations. ${ }^{88}$ These theorists contemplate, as does Aristotle, the possibility of a single individual capable of deliberating well. And they appear to agree with him that practical wisdom is not possessed by human beings equally. ${ }^{89}$

The legal theorists discussed in the preceding section appear to regard the consent of people to the laws governing them as important primarily because of the necessity in a democracy of ensuring voluntary support for and obedience to the laws. This necessity is practical, i.e., to avoid civil disobedience, lawlessness, or excessive coercion to uphold the law, but it is based as well on part of the core meaning of democratic government. Aristotle would agree that consent of the people is desirable 
to secure voluntary obedience to laws. He would, however, emphasize more than most contemporary theorists the role of habit in assuring consent and voluntary obedience as well as for instilling in people a sense of the goodness of their laws. ${ }^{90}$ Aristotle would find that these theorists (with the exception of Kronman and, possibly, Eisgruber) overestimate the ability of people in general to conduct themselves in accordance with beliefs that are not supported by corresponding habits. Consent, Aristotle would argue, is not sufficient to ensure obedience to laws unless reinforced by compatible character traits.

Finally, all of the theorists discussed in the preceding section except Eisgruber agree that the practical wisdom of judges cannot operate successfully in certain situations without recourse to disciplines external to the law, in particular, moral and political philosophy. In the writings of Aristotle, in contrast, the source of the moral insights of the person possessing practical wisdom is far less certain. In many places in his writings, it is the moral virtue of the person who exercises practical wisdom, rather than reason, that seems to provide a moral compass to guide his decisions. ${ }^{91}$ Elsewhere Aristotle suggests that some kind of cognitive knowledge of the end of human action would be useful for guiding individuals in their pursuits, and he asserts that law is the product of "some sort of practical wisdom and intelligence. ${ }^{, 92}$ But Aristotle never claims explicitly that philosophy can or should direct the practical

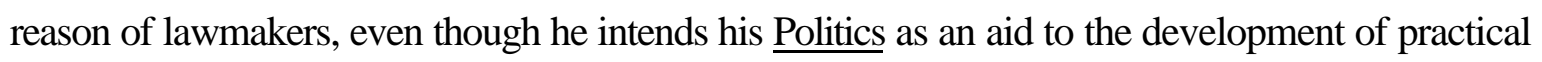
reason in the reader. ${ }^{93}$ Aristotle thus has less confidence than the contemporary theorists discussed in the ability of theoretical reason to direct human affairs absent the virtues of character, just as he believes practical reason and deliberation will fail to attain practical wisdom in their absence.

\section{$\underline{\text { Conclusion }}$}

Several themes have emerged through the preceding sketch that should give pause to 
contemporary middle-way legal theorists. First and foremost is the strong connection between deliberative excellence and character that Aristotle elaborates at length. Each, in his view, presupposes the other to be fully realized. Aristotle's understanding stands in stark contrast to that of contemporary middle way theory, which tends to views moral questions as fundamentally private matters, to be decided by each individual in accordance with his or her conscience. His understanding challenges this contemporary understanding by raising the possibility that insistence on a strong separation between moral education and education more generally will prevent the emergence of truly deliberative communities and leaders with practical wisdom.

Second, this sketch has brought to the fore fundamental assumptions of middle way theorists about human equality and inequality. Political equality is a central tenet of a liberal constitutional democracy, yet that fact does not and need not necessitate a comparable equality in every aspect of human life. For Aristotle, the capacity for practical reasoning appears to be unevenly distributed among the population, especially in the form of practical wisdom, which is limited by its very definition to people possessing a high degree of experience and commitment to "living well" in the Aristotelian sense, as contrasted with those adept at pursuing one or more partial goods. ${ }^{94}$ The legitimacy of Aristotle's insight is admitted tacitly in the writings of those authors who focus exclusively or disproportionately on the practical reasoning of judges, at the expense of other public officials and the population in general. Aristotle's ideas thus expose a conceptual difficulty at the core of theories of liberal constitutional democracy.

Finally, it is characteristic of liberal legal thought to be more comfortable investigating, discussing, and disagreeing about questions of method than about issues of human nature. The first 
book of the Nicomachean Ethics, in contrast, contain a powerful assertion of the inseparability of these two: all inquiry and knowledge about human affairs must take into account the complexity of the human soul and the consequences of that complexity for the possibilities of human conduct. This leads Aristotle to warn that it is inappropriate to expect the precision of mathematics in human inquiries. Wisdom about human affairs combines an appreciation of the reality of human commonality and the reality of human particularity with a sense of how these interact. It is thus part of the wisdom of middle-way theorists to be unsatisfied with those who would assimilate law to science or relegate it to complete subjectivity. And it is part of their wisdom to locate their project in the area between science and subjectivity because this is where the realities of human nature and human conduct reside. Theirs is the task of understanding and responding to the persistent conflicts between the rule of law and the pull of human particularity, between claims of right and the requirements of justice. In negotiating these extremes and what lies between, they would do well to turn to Aristotle both for support and enlightenment.

\section{END NOTES}

1. To some extent, these questions depend for their answers upon parallel questions raised by other disciplines, such as moral and political philosophy. Often, legal pronouncements raise distinct issues because they embody practical determinations made or to be made within the context of a specific Constitution or legal system. 
2. On legal formalism, see Ernest J. Weinrib, "Legal Formalism: On the Immanent Rationality of Law," 97 Yale Law Journal 949, 952 (1988). On legal realism, see the essays in William W. Fisher III, Morton J. Horwitz, and Thomas Reed, American Legal Realsim (1993). On sociological jurisprudence, see Roscoe Pound, "The Scope and Purpose of Sociological Jurisprudence," 25 Harvard Law Rev. 489 (1912). See also G. White, "From Sociological Jurisprudence to Realism: Jurisprudence and Social Change in Early Twentieth-Century America," 58 Virginia Law Rev. 999 (1972).

3. See Morris R. Cohen, Law and the Social Order 192-197 (1933). Dennis Patterson notes that both CLS and Formalists share the same vision of the ideal.

4. See Jerome Frank, Law and the Modern Mind 6-8, 10-11 (1930); Roscoe Pound, "The Scope and Purpose of Sociological Jurisprudence,” 25 Harvard Law Rev. 489 (1912).

5. Other important theoretical perspectives that can be considered formalist in inspiration are the law and economics movement and the analytical positivists, such as H.L.A. Hart, inspired by John Austin.

6. The major figures associated with the modern turn to natural law in legal theory are Lon Fuller, Lloyd L. Weinrib, Russell Hittinger, John Finnis, and Michael Moore. See Robert P. George, ed., Natural Law Theory: Contemporary Essays (1992); Charles Covell, The Defence of Natural Law (1992).

7. See generally Andrew Altman, Critical Legal Studies: A Liberal Critique (1990); Mark Kelman, $\underline{A}$ Guide to Critical Legal Studies (1987); John Stick, "Can Nihilism Be Pragmatic," 100 Harvard Law Rev. 332, 333 n.2 (1986) (arguing that CLS encompasses both nihilists and non-nihilists and that the 
nihilists "tak[e] nihilist critical arguments to state general truths," whereas the non-nihilists merely use nihilist arguments to "point[...] out local flaws in particular arguments").

8. Critical race theory is an approach to the study of law that examines the racial (and racist) history and racial (and racist) consequences of seemingly race-neutral laws. The method of critical race theory emphasizes the experiences and subjective interpretations of individuals of color, makes use of interdisciplinary (e.g., social science) studies of race and racism, and it aims at clarifying the conditions of and obstacles to meaningful legal reform. For the literature by and about critical race theorists, see Richard Delgado and Jean Stefancic, "Critical Race Theory: An Annotated Bibliography," 79 Virgina Law Rev. 461 (1993) and Delgado and Stefancic, "Critical Race Theory: An Annotated Bibliography 1993, A Year of Transition,” 66 U. Colorado Law Rev. 159 (1995). Although critical race studies are dominated by works by and about black and Afro-American experiences, there is a burgeoning critical race movement by and about Asian-American and Latino authors. See Robert S. Chang, "Toward an Asian American Legal Scholarship: Critical Race Theory, Post-Structuralism, and Narrative Space,” 81 California Law Rev. 1241 (1993).

9. See, e.g., Lucinda M. Finley, “Breaking Women's Silence in Law: The Dilemma of the Gendered Nature of Legal Reasoning,” 64 Notre Dame Law Rev. 886 (1989). Feminist jurisprudence encompasses a broad range of attitudes toward the possibility and desirability of political or moral truth. On the methods of different types of feminism, see Tracy E. Higgins, "By Reason of Their Sex: Feminist Theory, Post-Modernism, and Justice,” 80 Cornell Law Rev. 1536, 1592 (1995) (arguing that feminists are not necessarily relativists; properly understood, "antifoundationalism undercuts both 
objectivism and relativism"); Janet Radcliffe Richards, "What Feminist Epistemology Isn't (and the Implications for Feminist Jurisprudence)," 1 Legal Theory 365 (1995); Joan C. Williams, “Deconstructing Gender,” 87 Michigan Law Rev. 797, 802-06 (1989). See also Catharine MacKinnon, “Toward Feminist Jurisprudence,” 34 Stanford Law Rev. 703 (1982).

10. See, e.g., William N. Eskridge, Jr., "Gay Legal Narratives,” 46 Stanford Law Rev. 607 (1994). See also Symposium, “Legal Storytelling,” 87 Michigan Law Rev. 2073 (1989); Robin West, "Jurisprudence As Narrative: An Aesthetic Analysis of Modern Legal Theory," 60 New York Univ. Law Rev. 145 (1985). For criticism of storytelling as a source of legal standards, see the authorities cited in Eleanor Marie Brown, "Note: The Tower of Babel: Bridging the Divide Between Critical Race Theory and 'Mainstream' Civil Rights Scholarship,’ 105 Yale Law Journal 513, 516 n.11 (1995).

11. See Stephen M. Feldman, "Diagnosing Power: Postmodernism in Legal Scholarship and Judicial Practice (With an Emphasis on the Teague Rule Against New Rule s in Habeas Corpus Cases),” 88 Northwestern Univ. Law Rev. 1046, 1102-04 (1994) (including critical race theory and feminism among different voice approaches to scholarship and noting that the classification of different voice scholarship as a type of postmodernism can undermine the uniqueness and effectiveness of that scholarship).

12. The term "postructuralism" is often equated with the term "postmodernism." Postmodernism can, however, be seen as a broader term, encompassing poststructuralism as well as other movements. See Gary Minda, Postmodern Legal Movements: Law and Jurisprudence at Century's End 229-32 (1995) 
(dividing postmodernism into poststructuralism and neopragmatism); Peter C. Schanck, "Understanding Postmodern Thought and Its Implications for Statutory Interpretation,” 65 So. California Law Rev. 2514-15 (1992).

13. Suzanna Sherry, "The Sleep of Reason," 84 Georgetown Law Journal 453, 465, 472 (1996) (criticizing those who repudiate the priority of reasoned argument over other modes of knowing and suggesting "parallels between religious beliefs and the alternative nonrational epistemologies offered by the critical scholars"). See also Martha C. Nussbaum, "Skepticism about Practical Reason in Literature and the Law,” 107 Harvard Law Rev. 714 (1994) (characterizing the views of several prominent legal and political theorists as "attack[ing] certainty and justification rather than belief and commitment").

14. I use "foundationalism" or "objectivism" on the one hand and "relativism" or "subjectivism" on the other to refer to the two outer poles of the epistemological continuum. Good working definitions of these terms are given by Richard Bernstein, Beyond Objectivism and Relativism: Science, Hermeneutics, and Praxis 8 (1983). According to Bernstein, relativism views concepts as "relative to a specific conceptual scheme, theoretical framework, paradigm, form of life, society, or culture....there is no substantive overarching framework or single metalanguage by which we can rationally adjudicate or universally evaluate competing claims of alternative paradigms." Objectivism assumes that "there is or must be some permanent, ahistorical matrix or framework to which we can ultimately appeal in determining the nature of rationality, knowledge, truth, reality, goodness, or rightness." Id. Contrast Owen Fiss, "Objectivity and Interpretation,” 34 Stanford Law. Rev. 739, 748-49 (1982) (arguing that 
objectivity in judicial interpretation is different from correctness insofar as interpretation is objective if it is "constrained by disciplining rules," whereas correctness is a more rigorous standard).

15. The term "radical particularism" comes from Margaret Jane Radin and Frank Michelman, “Commentary, Pragmatist and Poststructuralist Critical Legal Practice," 139 Univ. Pennsylvania Law Rev. 1019, 1046, 1049 (1991) (referring to pragmatic and feminist thinkers who dismiss the meaningfulness or utility of rules altogether).

16. The term is from Suzanna Sherry, "The Sleep of Reason," supra note 12, at 458, 472-73.

17. Frank Michelman, citing Drucella Cornell, also uses the term "decisionism," defined as "the conviction that moral choice proceeds not from publicly certifiable grounds of reasoning, but from the inexplicable private impulses of individuals, objectively unfounded and rationally unguided." Michelman, “The Supreme Court, 1985 Term-Forward: Traces of Self-Government," 100 Harvard Law Rev. 4, 25 (1986).

18. On nihilism as it pertains to legal theory, see Joseph W. Singer, "The Player and the Cards: Nihilism and Legal Theory,” 94 Yale Law Journal 1 (1984); Stick, “Can Nihilism Be Pragmatic?,” supra note 7. Singer distinguishes nihilism from irrationalism: the former accepts that moral knowledge presupposes a rational foundation and a rational method, but denies that such things are possible; the latter agrees that rational moral knowledge is impossible, but believes that such knowledge is not necessary "to develop passionate commitments and to make our lives meaningful." Singer, "The Player and the Cards: Nihilism and Legal Theory," at 4 n.8. Thus, the nihilist despairs of living a meaningful 
life, while the irrationalist does not. Singer identifies himself with the latter view: rational truth and objectivity are unavailable, but we can nonetheless live a life of goals, caring, and commitment. He also suggests that "pragmatist" would adequately describe an irrationalist of this kind. His deepest criticism of traditional legal thought maintains that the dichotomies of rationality and irrationality, or objectivity and subjectivity, do not adequately describe our moral and epistemological choices.

19. Aristotle Nicomachean Ethics 1.3 1094b12-25 (all translations of the Nicomachean Ethics are those of Martin Ostwald unless otherwise noted). See also id. 6.5 1140a33-1140b3 ("things whose starting points or first causes can be other than they are do not admit of demonstration") .

20. For discussion by legal theorists about the character and significance of indeterminacy in legal reasoning, see Brian Leiter, "Legal Indeterminacy,” 1 Legal Theory 481 (1995); John Hasnas, “Back to the Future: From Critical Legal Studies Forward to Legal Realism, or How Not to Miss the Point of the Indeterminacy Argument," 45 Duke Law Journal 84 (1995); Ken Kress, "Legal Indeterminancy," 77 California Law Rev. 283 (1989).

21. See Aristotle Nicomachean Ethics $6.51140 \mathrm{~b} 4-7$ (practical wisdom "is a truthful characteristic of acting rationally in matters good and bad for man"). See also id. 6.2 1139b11-13 ("truth is the function of both intellectual parts [of the soul]," i.e., the theoretical and the practical).

22. The following discussion does not exhaust the types of contemporary liberal legal theory nor the important individual representatives of the two approaches discussed. These omissions are a consequence of space limitations. 
23. See Daniel Farber and Philip Frickey, "Practical Reason and the First Amendment," 34 Univ. California at Los Angeles Law Rev. 1615, 1645-47 (1987); Cass R. Sunstein, Legal Reasoning and Political Conflict ix, 45-46, 56-58, 99 (1997).

24. As others have noted, however, liberal theorists have a tendency to promote values such as tolerance, cooperation, neutrality, and autonomy, which, though themselves substantive values, are thought to be structural or minimal conditions to enable individuals to pursue their own life plans as they conceive them. See Stephen Gardbaum, "Liberalism, Autonomy, and Moral Conflict," 48 Stanford Law Rev. 385 (1996) (criticizing this tendency and arguing that, correctly understood, liberalism should promote choice and autonomy as substantive values).

25. See, e.g., Michael J. Perry, “Toward an Ecumenical Politics,” 60 George Washington Law Rev. 599 (1992); Robin West, “Liberalism Rediscovered: A Pragmatic Definition of Liberal Vision,” 46 Univ. Pittsburgh Law Rev. 673, 673-74, 680-83 (1985); Bruce Ackerman, Social Justice in the Liberal State (New Haven \& London: Yale UP 1980).

26. See, e.g., Michelman, “Traces of Self-Government,” supra note 17, at 4; Cass R. Sunstein, "Beyond the Republican Revival," 97 Yale Law Journal 1539 (1988); Bruce Ackerman, We the People. Vol. I, Foundations (Cambridge, Mass.: Harvard University Press, 1991).

27. See, e.g., Frank I. Michelman, “Law’s Republic,” 97 Yale Law Journal 1493, 1524-29 (1988) (the participants in a communal decision making process create the normative standards through the 
discussion); Suzanna Sherry, "Civic Virtue and the Feminine Voice in Constitutional Adjudication," 72 Virginia Law Rev. 543, 548 (1986). West, “Liberalism Rediscovered,” supra note 25, at 673-74, 68083 (the nature of the good life can only be known through the process of communal inquiry).

28. See, e.g., Aristotle Nicomachean Ethics 1.5-6.

29. Aristotle Topics 1.1 100a18-20, 100a30-b18. Although Aristotle does not mention practical reason in his account of the functions of the art of dialectic, it seems that the method could be used to evaluate moral beliefs and certain practical decisions as well as to test the ultimate principles of the sciences. See id. 1.2 101a36-b3.

30. See Aristotle Topics 1.2 101a34-36 ("For the philosophic sciences it is useful, because, if we are able to raise the difficulties on both sides, we shall more easily discern both truth and falsehood on every point").

31. Aristotle Topics 1.1 100b21-23.

32. Aristotle certainly sees the usefulness of face-to-face encounters. Aristotle's account of dialectical encounters for the sake of training (which appears to aim at beating one's opponent as opposed to seeking the truth) would seem to require live encounters to be effective.

33. The arguments in Aristotle's writings are almost exclusively dialectical, which is not what one would expect from the first philosopher to write systematically about the nature of syllogistic and demonstrative reasoning. 
34. See supra note 31 .

35. Not coincidentally, the Greek word for "generally accepted opinion" (endoksa) is sometimes translated as "probable opinion."

36. See Aristotle Politics 3.4 1277a27-28; see also id. 1277b13-30 (when the city is made up of people who are equal and free, the good man has the capacity to rule and be ruled both).

37. Aristotle Politics 3.4. 1277b25-26.

38. Aristotle Politics 3.4 1277b29-30.

39. Some middle-way legal theorists emphasize the quality of assent as well as the fact of assent. See below, pp. 14-15.

40. Although liberal legal theorists of the kind under discussion are often opposed to society imposing its (particular) understanding of good character on individuals, they almost uniformly assume or attempt to create a cluster of moral virtues supportive of the basic features of a liberal society. See the discussion in Miriam Galston, “Taking Aristotle Seriously,” 82 California Law Rev. 331, 361-69 (1994). A critical difference between their approach and that of Aristotle is that they seek a voluntary situation in which such virtues are likely to arise spontaneously.

41. Aristotle believed that moral virtue was a result of habit in the first instance. As a consequence, it is easier to acquire moral habits if one does not have to first "unlearn" bad habits. 
42. See Galston, "Taking Aristotle Seriously, supra note 40, at 372-76.

43. See Perry, “Toward an Ecumenical Politics," "Freedom of Communicative Action: A Theory of the First Amendment Freedom of Speech," 83 Northwestern. Univ. Law Rev. 54, 79-80 (1989) (describing and criticizing the theory of selfrealization through speech).

44. Aristotle Politics 1.2 1253a.

45. See, e.g., Ackerman, We the People, supra note 26, at 230-31; Michelman, "Traces of SelfGovernment," supra note 17 , at 22-23.

46. Among those who fail to make a sharp distinction between the political and the social are Fred Dallmayr, "Nature and Community: Comments on Michael Perry," 63 Tulane Law Rev. 1405 (1989); Mark Tushnet, Red, White, and Blue: A Critical Analysis of Constitutional Law 10 (1988); Solum, "Freedom of Communicative Action: A Theory of the First Amendment Freedom of Speech," supra note 43, at 54, 80; Michael J. Perry, Morality, Politics, and Law 11 (1988); Ronald R. Garet, “Communality and Existence: The Rights of Groups,” 56 S. California Law Rev. 1001, 1070-71 (1983). Some contemporary legal theorists have recognized the special meaning that Aristotle attributes to the term "political." See, e.g., Stephen M. Feldman, "Republican Revival/Interpretive Turn,” 1992 Wisconsin Law Rev. 679, 689-90.

47. Aristotle Politics 1.2 1252a-b. 
48. Aristotle Politics 1.2 1252b29-30 (the city comes into existence for the sake of living, but it exists for the sake of living well); see also $\underline{\text { id. }} 3.9$ 1280b38-1281a10 (contrasting the goal of living together, which is the aim of sub-political associations, with that of living well, acting nobly, and acquiring political virtue, which are the object of political association).

49. Aristotle Politics 1.1 1252a.

50. My criticism of the confusion between "social" and "political" would not apply to the term "social" when used in a comprehensive manner such as in the phrase "social science." According to Stephen Salkever, the contemporary term "social science," which includes political science, anthropology, sociology, psychology, economics, and history, appears to be what Aristotle meant by "political science" as the term is used in the Politics and the Nicomachean Ethics. Stephen G. Salkever, Finding the Mean: Theory and Practice in Aristotelian Political Philosophy 59-60 (Princeton, N.J. 1990).

51. The literature is vast. See John M. Cooper, Reason and the Human Good in Aristotle (Cambridge, Mass. 1975 ).

52. See Politics 1.2 1252b27-30 (self-sufficiency), 1253a7-18 (human beings are the most political of all gregarious animals because they have reason ( $\underline{\log 0 s}$, or "speech"), which makes possible perception of good and evil, just and unjust).

53. Sunstein, "Beyond the Republican Revival," supra note 26, at 1573.

54. Michelman, “Law's Republic,” supra note 27, at 1531. Michelman's list includes social or 
recreational clubs; schools; management, directorates, and leadership groups of all types of organization; workplaces and shop floors; and public events and street life as well as the more traditional town meetings and civic and voluntary organizations mentioned by Sunstein.

55. These characteristics are often rejected by liberal legal theorists today. See Kathleen M. Sullivan, "The Supreme Court, 1991 Term: Foreword: The Justices of Rules and Standards," 106 Harvard Law Rev. 21, 68 (1992); Robin West, “The Supreme Court, 1989 Term: Foreword: Taking Freedom Seriously," 104 Harvard Law Rev. 61 (1990).

56. For a critique of this kind, see Kathryn Abrams, "Rainbow Republicanism," 97 Yale Law Journal 1713, 1714 (1988) (suggesting that informed decision-making in clubs, workplaces, and other associations will not provide an experience equivalent to engagement in political life). The comments in the text do not necessarily apply to participation in local government, although such activity may be viewed as involvement in intermediate associations. See Richard Briffault, "Our Localism: Part II-Localism and Legal Theory," 1990 Columbia Law Rev. 346, 393-99.

57. Sunstein, "Beyond the Republican Revival," supra note 26, at 1573. His claim about obtaining a sense of community and an opportunity to participate in deliberative activities through such organizations is more credible. But the strong bonds that one forms within these partial communities may well increase the assurance on the part of their members of the rightness of their parochial interests and, thus, make it more difficult for them to consider fairly the demands of the public interest, which sometimes require self-sacrifice. This problem would appear to be accentuated by Sunstein's recommendation that 
private or intermediate associations be insulated from the state, although he also says that without government regulation such organizations may be a source of "oppression" and lead to "intolerable results." $\underline{\mathrm{Id}}$. at 1574.

58. See Solum, "A Theory of the First Amendment Freedom of Speech,” supra note 44, at 96-99; Michelman, "Traces of Self-Government," supra note 17, at 31-32, cf. Frank I. Michelman, "Family Quarrel," 17 Cardozo Law Rev. 1163 (1996) (discussing his reliance upon and disagreement with the theory of communicative action of Jürgen Habermas).

59. See Jürgen Habermas, "What is Universal Pragmatics?" in Communication and the Evolution of

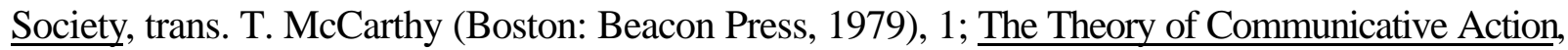
Vol. I: Reason and the Rationalization of Society, trans. T. McCarthy (Boston: Beacon Press, 1984), 25; Moral Consciousness and Communicative Action, trans. C. Lenhardt and S. Nicholsen (Cambridge, Mass.: MIT Press, 1990), 89.

60. See Solum, “A Theory of First Amendment Freedom of Speech,” supra note 43, at 97. 61. When the conditions are less than optimal, there is the risk that real persuasion and consensus are not reached, even if the participants arrive at a unanimous result. For example, those who are more articulate or present arguments based upon better factual premises will sound more authoritative. Indicia of power on the part of some speakers, such as their education, dress, or social and professional positions, may intimidate others or make them persuasive for the wrong reasons. Some people may agree to join the consensus out of a desire to achieve group harmony. For all their promise, deliberative 
encounters may fail in their aspirations even if no person or persons deliberately attempt to manipulate the conversation toward their own preferences.

62. In addition, imposing these structural conditions amounts to imposing a moral code in the guise of neutral ground rules, thus admitting through the back door what would be rejected at the front.

63. Aristotle Nicomachean Ethics 6.5 1140b11-19.

64. See Aristotle Nicomachean Ethics 6.8 (noting that young men do not display practical wisdom because they lack experience, an essential ingredient).

65. Aristotle Nicomachean Ethics 6.5 1140a24.

66. See Aristotle Nicomachean Ethics 6.5-9, 11.

67. The generalizations expressed in this paragraph are based upon numerous thinkers whose views differ in many important respects, although they share the attributes discussed in the text in common. Some of these thinkers are mentioned in the text and notes that follow.

68. For a useful summary of the views of such thinkers and citations to their writings, see Sherry, "The Sleep of Reason," supra note 13.

69. See, e.g., the essays by David Brink, Joseph Raz, and Philip Pettit in Brian Leiter, Objectivity in Law and Morals (Cambridge University Press, 2001). The following authors imply that some form of moral truth is possible and discuss the extent to which moral philosophy or moral truth should have a role in shaping the lives of individuals or legal regimes: Ken Kress, "Why No Judge Should Be a 
Dworkinian Coherentist," 77 Texas Law Rev. 1375 (1999); Anthony T. Kronman, "Response: the Value of Moral Philosophy," 111 Harvard Law Rev. 1751 (1998), "Living in the Law," 54 Univ. of Chicago Law Rev. 835 (1987); Christopher L. Eisgruber, "Justice and the Text: Rethinking the Constitutional Relation between Principle and Prudence," 43 Duke Law Journal 1 (1993).; Joseph Raz, “Liberalism, Skepticism, and Democracy,” 74 Iowa Law Rev. 761 (1989); Ronald Dworkin, Taking

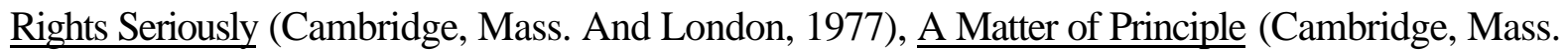
1985), Law’s Empire (Cambridge, Mass. and London, 1986).

70. Dworkin also believes that political officials should justify their decisions in terms of such a theory. Dworkin, Taking Rights Seriously, supra note 69, at pp. 87, 106 (arguing that if a member of Congress votes to prohibit abortion, he should vote on all relevant issues to uphold the sanctity of life). However, he recognizes that this is unlikely for politicians, citizens, and political commentators most of the time.

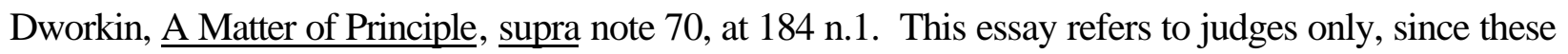
theorists seem to have them in mind most of the time.

71. According to Dworkin, there are often or generally right answers in cases where there is not a clear, dispositive precedent or rule. See Dworkin, Taking Rights Seriously, supra note 69, at 143, 279, 365. Although Dworkin's theory has evolved, I believe that the core concept has remained fundamentally the same, namely, that public officials who make decisions within a legal system should rely on a mixture composed of established legal materials and moral or political philosophy when confronting situations not controlled by settled law. For the view that Dworkin's thought has changed significantly, see Joseph Raz, "Dworkin: A New Link in the Chain," 74 California Law Rev. 1103, 
1116 (1986).

72. For the difference between "principles," "policies," and "goals," see Dworkin, $\underline{\text { Taking Rights }}$ Seriously, supra note 69, at 22-23, 90; A Matter of Principle, supra note 70, at 2-3, 11, 69. He advocates using principles implicit in established legal materials to reach legal judgments because of his conviction that the moral, political, and social values from which legal rules and precedents derive are themselves an integral part of law. $\underline{\text { Id., }}$ at 29-30.

73. Dworkin, Taking Rights Seriously, supra note 69, at 87.

74. Dworkin, Taking Rights Seriously, supra note 69, at 87.

75. Dworkin, A Matter of Principle, supra note 70, at 107-08, 143, see also id at 161, Taking Rights Seriously, supra note 69, at 113.

76. Thus, for Dworkin the path to truth in judicial reasoning does not follow a formula and disagreements about which practical decisions are correct are possible and even likely.

77. Ken Kress, "Coherentist Methodology Is Morally Better Than Either Its Proponents or Its Critics Think (But Still Not Good Enough),” 12 Canadian Journal of Law \& Jurisprudence 83, 94 (1999) (explaining that Dworkin insists on a high level of fit with settled law in order to maintain a high degree of consensus among people governed by the law).

78. Kress, "Coherentist Methodology Is Morally Better," supra note 77.

79. Kress, "Coherentist Methodology Is Morally Better, supra note 77, at 94-95, Kress, "Why No 
Judge Should Be a Dworkinian Coherentist,"supra note 69, at 1392, 1415.

80. Kress, "Why No Judge Should Be a Dworkinian Coherentist,” supra note 69, at 1420.

81. These are: to preserve the law by understanding the "background conditions that give laws their meaning, purpose, and aspirational force"; to articulate the collective values and commitments embodied in law; and to diminish the extent of moral conflicts by promoting a regime of tolerance Kronman, "Response: the Value of Moral Philosophy," supra note 69, at 1761-63.

82. Kronman, "Response: the Value of Morals Philosophy, supra note 69, at 1761-62.

83. See Anthony T. Kronman, “Alexander Bickel’s Philosophy of Prudence,” 94 Yale Law Journal 1567, 1570 (1985). Kronman again defers to Bickel in "Response: the Value of Moral Philosophy," supra note 69 , at 1761 .

84. Kronman gives the impression in his 1985 article that he largely concurs with the views that he attributes to Bickel.

85. Kronman, “Alexander Bickel's Philosophy of Prudence,” supra note 83, at 1580-81.

86. See Kronman, “Alexander Bickel's Philosophy of Prudence,” supra note 83, at 1570-71.

87. See Eisgruber, "Justice and the Text," supra note 69, at 2, 14, 15-18.

88. See Aristotle Nicomachean Ethics $6.81141 \mathrm{~b}-1142 \mathrm{a}$.

89. Dworkin is the clearest example: he calls the judge who can get right answers in hard cases "Hercules," to indicate the extraordinary character of the task he has to perform. In contrast, in his writings, Kronman appears to recommend that individuals in general, and lawyers in particular, should 
(and, by implication, can) work at developing their practical reasoning faculties. See Kronman, "Living in the Law," supra note 69, "Response: the Value of Moral Philosophy," supra note 69, at 1753, $1755-59,1761-64$.

90. See Aristotle Nicomachean Ethics 2.1 1103a-b5, 3.1 1109b34, 10.9 1179b20-1180a18.

91. See Aristotle Nicomachean Ethics 6.12 1144a, 6.13 1145a; but see id. 10.8 1178a (stating that the principles of practical wisdom are in accordance with the moral virtues and correctness in morals is in accordance with practical wisdom) (emphasis added).

92. See Aristotle Nicomachean Ethics 1.1-2, 10.9 1180a18-19. The ambiuguity in Aristotle's writings referred to in the text is discussed in Galston, Taking Aristotle Seriously, supra note 40, pp. 372-75.

93. See Aristotle, Nichomachean Ethics, 10.9 1180a18-25,33 (a person who seeks to help others to live well needs to know "something about legislating" — the topic elaborated by Aristotle in the Politics). See also id. 1180b13-25 (suggesting that knowledge of general rules is typically useful although not absolutely necessary).

94. See especially Aristotle, Nichomachean Ethics 6.12 1144a23-30, see also id. 6.8 1142a11-16. 